\title{
The International Conference on Tissue Science and Engineering 2012: News on Emerging Cell - Based Therapies?
}

\section{Melanie L Hart, Jan K Maerz and Wilhelm K Aicher*}

University of Tuebingen Hospital (UKT), Tuebingen Germany, Germany

In October 2012 the OMICS Group held an International Conference on Tissue Science and Engineering, and stem cells and biomaterials were or course among the hot topics. Here we review briefly current developments on emerging cellular therapies and point to some of the presentations of the OMICS conference related to stem cells.

The prototype of all stem cells is the pluripotent stem cell generated from the inner cell mass of a blastocyst. Such pluripotent cells are therefore called embryonic stem cells (ESC). Their artificial counterpart of ESC are the recombinantly induced pluripotent stem cells (iPSC) generated by overexpression of key factors required to maintain the transcriptome and epigenetics of a truly pluripotent cell: NANOG, OCT4 and SOX2 [1,2]. In addition, to increase the cloning efficacy, in some cases a growth-promoting factor such as MYC is employed, and to ensure sufficient telomer lengths for extended expansion of the cells the enzyme telomerase (TERT) is expressed as well. The pluripotent stem cells allow generation of all cell types and lineages of cells found in an adult individual. They therefore inspired the field of regenerative medicine. Hope was high that iPSC will open new avenues to all cells needed for therapy. However a simple application of recombinant iPSC for therapy in an adult patient may yield a very high risk to develop cancer, as iPSC tend to generate teratomas [3-5]. Therefore many approaches were developed for transient expression of the factors needed for maintenance of pluripotence in somatic cells.

An interesting approach to generate pluripotent cells is the transfection of target cells with stabilized mRNA encoding the abovementioned factors NANOG, OCT4, SOX2 and TERT [6]. The resuting pluripotent cells are called RNA-induced pluripotent cells (RiPSC). In these cells, the half-live time of RNA is rather short. Therefore the induction of pluripotence by RNA remains transient and the genome of the cells treated is not mutated in RiPSC. In addition, by introducing RNA instability motives (AUUUA) or their mutation, or by suitable stabilizing elements (e.g. SV40 poly-A-tail) the half-life time of the therapeutic RNA can be customized. When sufficient numbers of RiPSC are produced, transfection of the cells with NANOG, OCT4, SOX2 and TERT is halted for a few days, the stage of pluripotence ends, and the cells can then be utilized for diagnostic purposes. Using the same approach - transfection of the cells with stabilized mRNA differentiation of RiPSC to effector cells or more mature types of cells can be induced [6]. It was shown that muscular differentiation was induced by transfection of the RiPSC with MyoD, a key transcription factor involved in differentiation of striated muscle cells Warren, 2010 \#49.

An important concern for tissue engineering and regenerative is the quality of cells to be applied and human adult mesenchymal stromal cells (MSC), previously called mesenchymal stem cells, hold great promise for regenerative medicine. Human MSC are under investigation for more than a decade now [7-11]. However not all clinical or therapeutic issues with MSCs are addressed in a satisfactory way. The age of the donor and therefore the cell is one of the concerns.

In his presentation at the convention Dr. David T. Harris (Univ. of
Arizona, USA) pointed out that in general, younger stem cells perform better than older stem cells. Many studies have provided evidence that stem cells from younger donors yield better results compared to stem cells from older donors [12-14]. The above-mentioned RiPSC approach could therefore represent the "Jungbrunnen" (fountain of youth) as painted by the famous Lucas Cranach in 1546. Treating autologous cells from the (elderly) patient with the RiPSC method may represent a rescue from the "trap of age". This however must be proven with outmost care in suitable in vitro studies and in vivo models before being applied to humans.

Another hot topic at the OMICS convention was of course biomaterials, and especially the modification of stiffness, elasticity, hydrophobicity, and structure of the scaffold. It has been shown that differentiation of stem cells not only depends on soluble signals such as growth factors, cytokines, hormones or low molecular weight components (e.g. nutrients, oxygen, radicals) [15], but also on the signals provided by the extracellular matrix or immediate pericellular environment $[16,17]$, and of course on the elasticity of the substratum [18] [19].

However, chronic inflammation confronts stem cells with an overdosis of cytokines, growth factors, and even nitric oxide radicals. This may contribute to malfunction of the stem cells and cause malignancies, as Dr. Mahin Khatamin (NIH, Bethesda, USA) explained at the OMICS conference. Unresolved chronic inflammation may tip the balance between tumoricidal or tumorigenic pathways, cell death (apoptosis) on one side, and wound healing or differentiation on the other side. Here controlling chronic inflammation seems the solution for the problem.

Biomaterials are important to maintain the phenotype of a cell, and keep the cells alive and in place for regeneration. Elastic, microporous and nano-surfaced hydrogels were instrumental for supporting microglia cells in neuronal repair in a spinal cord injury model, as Dr. Eugen P. Goldberg (Univ. of Florida, USA) pointed out. These nano-structured surfaces allowed cell-matrix binding, and the porous scaffold acted as reservoir for growth factors. Therefore, all players are in place: the cell and the fuel it needs to do the job.

Overall the OMICS meeting covered very interesting topics. It

*Corresponding author: Wilhelm K Aicher, Dept. of Urology, TTR Research Buildg.,University of Tuebingen Hospital (UKT) Paul-Ehrlich-Str. 15, 72076 Tuebingen, Germany, Tel: +49 7071298 7020; Fax: +49 7071292 5072; E-mail: aicher@uni-tuebingen.de

Received March 26, 2013; Accepted March 27, 2013; Published March 29, 2013

Citation: Hart ML, Maerz JK, Aicher WK (2013) The International Conference on Tissue Science and Engineering 2012: News on Emerging Cell - Based Therapies? J Tissue Sci Eng S11: e001. doi:10.4172/2157-7552.S11-e001

Copyright: $\odot 2013$ Hart ML, et al. This is an open-access article distributed under the terms of the Creative Commons Attribution License, which permits unrestricted use, distribution, and reproduction in any medium, provided the original author and source are credited. 
Citation: Hart ML, Maerz JK, Aicher WK (2013) The International Conference on Tissue Science and Engineering 2012: News on Emerging Cell Based Therapies? J Tissue Sci Eng S11: e001. doi:10.4172/2157-7552.S11-e001

Page 2 of 2

offered great opportunities to contact experts from all over the globe. It was a success!

\section{References}

1. Takahashi K, Tanabe K, Ohnuki M, Narita M, Ichisaka T, et al. (2007) Induction of pluripotent stem cells from adult human fibroblasts by defined factors. Cell 131:861 - 872

2. Takahashi K, Yamanaka S (2006) Induction of pluripotent stem cells from mouse embryonic and adult fibroblast cultures by defined factors. Cell 126:663676.

3. Prokhorova TA, Harkness LM, Frandsen U, Ditzel N, Schrøder HD, et al. (2009) Teratoma formation by human embryonic stem cells is site dependent and enhanced by the presence of Matrigel. Stem cells dev 18:47-54.

4. Zhang WY, De Almeida PE, Wu JC (2012) Teratoma formation: A tool for monitoring pluripotency in stem cell research.

5. Gutierrez-Aranda I, Ramos-Mejia V, Bueno C, Munoz-Lopez M, Real PJ, et al. (2010) Human induced pluripotent stem cells develop teratoma more efficiently and faster than human embryonic stem cells regardless the site of injection. Stem Cells 28:1568-1570.

6. Warren L, Manos PD, Ahfeldt T, Loh YH, Li H (2010) Highly efficient reprogramming to pluripotency and directed differentiation of human cells with synthetic modified mRNA. Cell stem cell 7: 618-630.

7. Pittenger MF, Mackay AM, Beck SC, Jaiswal RK, Douglas R (1999) Multilineage potential of adult human mesenchymal stem cells. Science 284:143-147.

8. Dominici M, Le Blanc K, Mueller I, Slaper-Cortenbach I, Marini F, et al. (2006) Minimal criteria for defining multipotent mesenchymal stromal cells. The International Society for Cellular Therapy position statement. Cytotherapy 8:315-317.

9. Parolini O, Alviano F, Bergwerf I, Boraschi D, De Bari C, et al. (2010) Toward cell therapy using placenta-derived cells: disease mechanisms, cell biology, preclinical studies, and regulatory aspects at the round table. Stem Cells Dev19:143-154

10. Felka T, Schäfer R, De Zwart P, Aicher WK (2010) Animal serum-free expansion and differentiation of human mesenchymal stromal cells. Cytotherapy 12:143 153

11. Caplan Al, Correa D (2011) The MSC: an injury drugstore. Cell stem cell 9:1115.

12. Kim M, Moon HB, Spangrude GJ (2003) Major age-related changes of mouse hematopoietic stem/progenitor cells. Ann N Y Acad Sci 996:195-208.

13. Carlson Carlson ME, Suetta C, Conboy MJ, Aagaard P, Mackey A (2009) Molecular aging and rejuvenation of human muscle stem cells. EMBO mol med 1:381-391.

14. Shen J, Tsai YT, Dimarco NM, Long MA, Sun X (2011) Transplantation of mesenchymal stem cells from young donors delays aging in mice. Sci rep 1: 67 .

15. Leroux L, Descamps B, Tojais NF, Séguy B, Oses P (2010) Hypoxia preconditioned mesenchymal stem cells improve vascular and skeletal muscle fiber regeneration after ischemia through a Wnt4-dependent pathway. Mol the 18:1545-1552.

16. Hashimoto J Kariya Y, Miyazaki K (2006) Regulation of Proliferation and Chondrogenic Differentiation of Human Mesenchymal Stem Cells by Laminin-5 (Laminin-332). Stem Cells 24: 2346-2354.

17. Klees RF, Salasznyk RM, Ward DF, Crone DE, Williams WA (2008) Dissection of the osteogenic effects of laminin-332 utilizing specific LG domains: LG3 induces osteogenic differentiation, but not mineralization. Exp Cell Res 314 763-773.

18. Engler AJ Sen S, Sweeney HL, Discher DE (2006) Matrix elasticity directs stem cell lineage specification. Cell 126:677-689.

19. Rowlands AS, George PA, Cooper-White JJ (2008) Directing osteogenic and myogenic differentiation of MSCs: interplay of stiffness and adhesive ligand presentation. Am J Physiol Cell Physiol 295:C1037-1044. 